\title{
Terror Financing, Guilt by Association and the Paradigm of Prevention in the 'War on Terror'
}

David Cole

Georgetown University Law Center, cole@law.georgetown.edu

Georgetown Public Law and Legal Theory Research Paper No. 1262792

This paper can be downloaded free of charge from:

https://scholarship.law.georgetown.edu/facpub/442

http://ssrn.com/abstract=1262792

Terror Financing, Guilt by Association and the Paradigm of Prevention in the 'War on Terror' in COUNTERTERRORISM: DEMOCRACY'S CHALLENGE (Bianchi \& Keller eds., Hart Pub. 2008)

This open-access article is brought to you by the Georgetown Law Library. Posted with permission of the author. Follow this and additional works at: https://scholarship.law.georgetown.edu/facpub

Part of the Constitutional Law Commons, Law and Society Commons, and the Law Enforcement and Corrections Commons 


\title{
GEORGETOWN LAW Faculty Publications
}

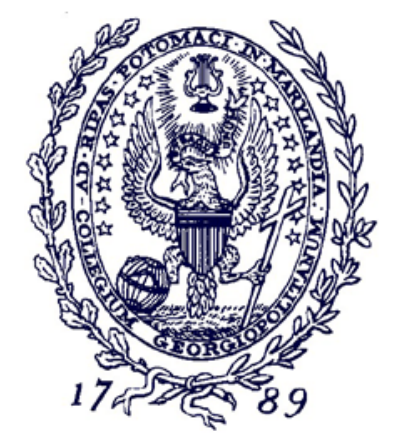

Georgetown Public Law and Legal Theory Research Paper No. 1262792

October 2010

\section{Terror Financing, Guilt by Association and the Paradigm of Prevention in the 'War on Terror'} in

\section{COUNTERTERRORISM: DEMOCRACY'S CHALLENGE (Bianchi \& Keller eds., Hart Pub. 2008)}

\author{
David Cole \\ Professor of Law \\ Georgetown University Law Center \\ cole@,law.georgetown.edu
}

This paper can be downloaded without charge from: Scholarly Commons: http://scholarship.law.georgetown.edu/facpub/442/ SSRN: http://ssrn.com/abstract $=1262792$ 
6

\title{
Terror Financing, Guilt by Association and the Paradigm of Prevention in the 'War on Terror'
}

\author{
DAVID COLE
}

\section{INTRODUCTION}

G UILT BY ASSOCIATION is an attractive principle to law enforcement officials concerned about preventing future harms. Without the concept of guilt by association, government officials must carry out costly investigations to catch individuals in the act of either committing a crime, or conspiring to commit one. Guilt by association, by contrast, permits the government to incarcerate persons based not on their involvement in past illegal conduct, and not even on their involvement in planning future crimes, but on the basis of their affiliation or association with others who have engaged in illegal conduct.

The United States' formative experience with guilt by association came during the Cold War. Fearing a communist takeover, Congress made membership in the Communist Party a criminal offense, in a statute known as the Smith Act. In 1961, in Scales v United States, the Supreme Court considered the validity of this law. ${ }^{1}$ The Court interpreted the statute narrowly in order to avoid the grave constitutional concerns that it said the statute would otherwise present. As the Court explained, the First Amendment right of association includes the right to associate with groups that have both legal and illegal aims, so long as the individual does not seek to further the group's illegal aims. In addition, the Fifth Amendment requires proof of 'personal guilt', and therefore precludes holding an individual criminally liable for the acts of another (group or individual) absent proof that the individual sought to further the other's illegal conduct. ${ }^{2}$ In the interest of avoiding the constitutional problems

1367 US 203 (1961).

2 Ibid, at 224-7. 
presented by a broad ban on membership, the Court in Scales interpreted the Smith Act to require proof that the defendant specifically intended to further the Communist Party's illegal ends. Mere association, or association in furtherance of the Party's legal ends (such as its civil rights advocacy or labour union organising), were insufficient to violate the statute. Only a showing of specific intent, the Court said, would distinguish those who seek to further illegal ends from those who associate for legal purposes. While the Court's decision in Scales was technically an interpretation of the statute, it was driven by its constitutional analysis, and subsequent cases treated Scales as establishing a constitutional principle, not just a reading of a specific statute. ${ }^{3}$

There the law essentially stood - until 11 September 2001. In the wake of the terrorist attacks of that day, the Bush administration aggressively pursued a theory of collective guilt that for all practical purposes revived the tactics of the Cold War. In the name of cutting off support for terrorist organisations, US law now makes it a crime to provide anything of support - from dues to volunteer services - to any organisation or individual that the government has label;ed 'terrorist'. 4 The prohibition is not limited to those who intend to support the illegal or terrorist acts of so-called terrorist organisations. It criminalises any and all support including support that is otherwise entirely lawful, peaceful and nonviolent. Indeed, the criminal bar applies even to aid that is designed to reduce a group's reliance on violence, and even where the aid can be shown to have had precisely that beneficial effect. ${ }^{5}$ Thus, the government has argued that the material support law prohibits a human rights group from providing human rights training to the Kurdistan Workers' Party in Turkey, even though the undisputed purpose of the training is to encourage that group to resolve its differences with the Turkish government through peaceful, non-violent, legal means. ${ }^{6}$

The government insists that these laws do not impose guilt by association, because the laws target not association per se, but 'material support', and several courts have accepted that distinction. ${ }^{7}$ But in the end, it is largely a distinction without a difference, for what good is it to have a right to join or associate with a group if the government can make it a

\footnotetext{
3 See, eg, NAACP $v$ Claiborne Hardware, 458 US 886, 932 (1982) (guilt by association violates the First Amendment).

4 See Section II below.

5 Ibid.

6 See Humanitarian Law Project v Reno, 205 F.3d 1130 (9th Cir 2000) (declaring prohibition on providing 'training' and 'personnel' to designated terrorist organisations unconstitutional because it could make it a crime to, for example, teach international law); Humanitarian Law Project v US Dept of Treasury, 473 F Supp 2d 1049, 1059-63 (CD Cal 2006) (upholding criminal ban on providing all 'services' to designated terrorist groups, where regulation defined services to include 'educational' and 'legal' services, among others).

7 See, eg, Humanitarian Law Project v Reno, 205 F.3d 1130.
} 
crime to do anything whatsoever on the group's behalf? No association can survive without the support of its members.

Just as the fear of future threats from communism in the Cold War spawned a sweeping approach that failed to distinguish between the culpable and the innocent, so too the fear of future terrorist attacks in the wake of 11 September 2001 has created a similar initiative. Moreover, through the United Nations, the United States has sought to encourage other nations to adopt a similar approach, with some success.

This chapter argues that the 'material support' principle is 'guilt by association' in twenty-first-century garb, and presents all of the same problems that criminalising membership and association did during the Cold War. I will first outline the ways in which guilt by association has been revived through the concept of penalising 'material support' for organisations labelled terrorist. I will then discuss the constitutional questions that these laws present, and sketch how the courts have, at least thus far, resolved those questions. In short, the courts have sought to trim the worst excesses of the laws, but have been largely unwilling to confront head on their fundamental infirmity - the imposition of guilt by association without any proof of intent to further any terrorist acts.

Finally, I will conclude by explaining how the material support laws fit into the United States' broader 'paradigm of prevention' in confronting the threat of terrorism. That term, coined by former Attorney General John Ashcroft, describes an amalgam of tactics in which the government employs highly coercive and intrusive measures against groups and individuals based not on proof of past wrongdoing, but on necessarily speculative fears about what they might do in the future. ${ }^{8}$ The material support laws further this goal by expanding the definition of what constitutes a past crime, just as the Smith Act membership provision of the Cold War era did. These laws are not purely preventive, in that they

\footnotetext{
8 Attorney General Ashcroft first announced this preventive policy in a speech to the US Conference of Mayors in October 2001. As he put it: 'Let the terrorists among us be warned: If you overstay your visa - even by one day - we will arrest you. If you violate a local law, you will be put in jail and kept in custody as long as possible. We will use every available statute. We will seek every prosecutorial advantage. We will use all our weapons within the law and under the Constitution to protect life and enhance security for America. In the war on terror, this Department of Justice will arrest and detain any suspected terrorist who has violated the law. Our single objective is to prevent terrorist attacks by taking suspected terrorists off the street': Prepared Remarks of Attorney General John Ashcroft for the US Mayors Conference, 25 October 2001, available at <http:/ / www.usdoj.gov / archive/ ag/speeches/2001/agcrisisremarks10_25.htm>. See also Prepared Remarks of Attorney General John Ashcroft, Council on Foreign Relations, 10 February 2003 ('In order to fight and to defeat terrorism, the Department of Justice has added a new paradigm to that of prosecution - a paradigm of prevention.'), available at <http://www.usdoj.gov/archive/ $\mathrm{ag} /$ speeches/2003 /021003agcouncilonforeignrelation.htm>.
} 
do require proof of some past 'wrongdoing'. But their expansive definitions of wrongdoing stretch that concept beyond its limits in the name of preventing future harm.

The same preventive justification that underlies the material support laws has also led the United States to embark on indiscriminate preventive detention schemes; to use highly coercive interrogation techniques amounting, at least in some circumstances, to torture; and to wage war 'preventively' against Iraq, a country that neither attacked the United States nor posed a threat of imminent attack. The centrality of the 'preventive paradigm' to the rationale for the material support laws suggests strong reason for scepticism about their fairness, and underscores the need for careful scrutiny of their application.

\section{THE LEGAL REGIME}

Three different federal laws authorise US officials to designate groups or individuals as 'terrorist' and then punish 'material support' provided to them. All three statutes share a common attribute - they penalise support of designated groups or persons without regard to the character or intent of the support provided, and without regard to the effect of the support in question. Thus, aid having nothing to do with terrorism, and even aid designed to discourage terrorism, is treated identically to aid designed to further terrorism. In addition, all three statutes afford federal officials wide discretion - a virtual 'blank cheque' - in selecting disfavoured groups or persons for designation. And all three statutes provide inadequate procedures for challenging designations.

\section{A. The Criminal 'Material Support' Statute - 18 USC §2339B and 8 USC $§ 1189$}

The Antiterrorism and Effective Death Penalty Act (AEDPA) of 1996, amended by the USA Patriot Act in 2001, and again in 2004, authorises the Secretary of State to designate 'foreign terrorist organizations', and makes it a crime for anyone to support even the wholly lawful, nonviolent activities of those designated organisations. ${ }^{9}$

The law works in two steps: designation and prohibition. As an initial matter, the Secretary of State

is authorized to designate an organization as a foreign terrorist organization ... if the Secretary finds that -

9 See 8 USC § 1189 and 18 USC § 2339B. 
(a) the organization is a foreign organization;

(b) the organization engages in terrorist activity; and

(c) the terrorist activity of the organization threatens the security of United States nationals or the national security of the United States. ${ }^{10}$

The term 'terrorist activity' is broadly defined far beyond its commonly understood meaning to include virtually any unlawful use of, or threat to use, a weapon against person or property, unless for mere personal monetary gain. 'National security' is also broadly defined to mean 'national defense, foreign relations, or economic interests of the United States'. The Secretary's determination that a group's activities threaten US 'national security' under the statute is judicially unreviewable. ${ }^{11}$ Thus, this statute is not limited to terrorist organisations as they are commonly understood, or to national security as it is commonly understood, but broadly empowers the Secretary to designate any foreign group that has used or threatened to use a weapon and whose activities are deemed contrary to the United States' economic interest.

The second step is the prohibition of support. Once the Secretary designates an organisation and publishes the designation in the Federal Register, it becomes a crime, punishable by up to 15 years of imprisonment (or life imprisonment if death results) and a substantial fine, to 'knowingly provide[] material support or resources to a foreign terrorist organization, or [to] attempt[] or conspire[] to do so'.12 'Material support or resources' is defined as:

any property, tangible or intangible, or service, including currency or monetary instruments or financial securities, financial services, lodging, training, expert advice or assistance, safehouses, false documentation or identification, communications equipment, facilities, weapons, lethal substances, explosives, personnel (1 or more individuals who may be or include oneself), and transportation, except medicine or religious materials. ${ }^{13}$

The statute does not on its face require any showing that the defendant intended that his donation be used for any illicit purpose. The United States maintains that Congress in effect adopted an irrebuttable presumption that all support to such organisations furthers their terrorist ends. ${ }^{14}$ In fact, Congress heard no testimony about any particular terrorist organisations that would support such a presumption even as to that

\footnotetext{
108 USC $\S 1189(a)(1)$.

11 People's Mojahedin Org of Iran v US Sec of State, 182 F.3d 17, 23 (DC Cir 1999), cert denied, 529 US 1104 (2000).

1218 USC $\S 2339 \mathrm{~B}(\mathrm{a})$.

1318 USC $\S 2339 \mathrm{~A}(\mathrm{~b})$.

14 Antiterrorism and Effective Death Penalty Act, Pub L No 104-132, § 301(a)(7), 110 Stat 1214, 1247 (24 April 1996).
} 
group, much less as to all groups that might henceforth be labelled 'foreign terrorist organisations'. At the same time, and directly contrary to this presumption, the statute permits the donation of unlimited amounts of medicine and religious materials to designated organisations. And a provision added in 2005 permits the Secretary of State and Attorney General to grant advance approval for aid in the form of 'training', 'personnel,' and 'expert advice or assistance' where the Secretary determines that the aid may not be used to carry out terrorist activity. ${ }^{15}$ Thus, the statute expressly discriminates between religious and political aid, permitting unlimited amounts of religious aid (even if it is intended to further terrorist activity), ${ }^{16}$ while barring all political aid, even if it counters terrorism and promotes peace.

Procedures for challenging designation are largely a sham. Once the Secretary of State designates a group and publishes that fact in the Federal Register, the designated group has 30 days to file a legal challenge in the federal court of appeals in Washington, DC. Even if it manages to learn of the designation, find a lawyer, and file the challenge in time, the review process is one-sided. The court does not consider any new evidence, but merely reviews the evidence the State Department developed unilaterally. The State Department is able to present the record in secret and behind closed doors, so the designated group in many instances will not even be able to see the evidence used against it. And as noted above, the critical criterion - that the group's activities threaten 'national security', - has been deemed unreviewable by the courts. ${ }^{17}$ Not surprisingly, no group has succeeded in challenging its designation under this law.

\section{B. Immigration Consequences of 'Material Support' under 8 USC $\S 1182$}

Immigration law also penalises 'material support', but does so even more expansively than the criminal law. Foreign nationals can be denied entry or deported for having provided material support not only to organisations designated as 'terrorist', but even to organisations that have never been designated terrorist, but merely have at some point threatened to use a weapon against person or property. In one case, for example, a

1518 USC $\S 2339 B(j)$.

1618 USC \& 2339A prohibits the provision of 'material support or resources' for the purpose of furthering specified terrorist activities, but then exempts the provision of 'medicine and religious articles' from the definition of 'material support'. Accordingly, even if an individual donated medicine for the purpose of furthering terrorist activity, his action would not be prohibited by the 'material support' provisions: 18 USC $\$ \S 2339 \mathrm{~A}$ and 2339B.

17 See $\mathrm{n} 11$ above. 
national of India was deported for having set up a tent for religious services that were then attended by, among others, some members of an Indian guerrilla organisation. ${ }^{18}$ Moreover, the Department of Homeland Security, which enforces immigration law, interprets this provision to apply even to those who are coerced into providing material support to such a group. Thus, if guerrillas ransack a village and demand food at gunpoint, anyone who relents and gives them food will, absent a waiver, be deemed inadmissible to the United States for having materially supported a terrorist group. ${ }^{19}$

In another case the government invoked these immigration provisions to seek the deportation of two long-time lawful permanent residents, Khader Hamide and Michel Shehadeh, for having provided 'material support' to a 'terrorist organization' by distributing PLO magazines in Los Angeles in the 1980s, when it was fully lawful to do so (the magazines were then and are still available in libraries across the nation). The government never alleged that Hamide or Shehadeh sought to further any illegal activities of the PLO group they were alleged to have supported. But under the government's view of the immigration law, that fact was irrelevant. (In October 2007, after a 21-year legal battle, and after an immigration judge dismissed the case for prosecutorial misconduct, the government abandoned its efforts to deport Hamide and Shehadeh).

\section{Embargoing Individuals and Groups under the International Emergency Economic Powers Act}

The third statute that the government relies upon to penalise support of 'terrorists' is the International Emergency Economic Powers Act (IEEPA). ${ }^{20}$ This statute was originally enacted to empower the President during emergencies to impose economic embargoes on foreign nations. It was used exclusively for that purpose until 1995, when President Bill Clinton first used it not to target nations as a matter of nation-to-nation diplomacy but to target disfavoured political groups. Clinton named ten Palestinian organisations and two Jewish groups as 'specially designated terrorists'. ${ }^{21}$ Designation under IEEPA has the effect of freezing the entity's assets in the United States and making it a crime for anyone in

\footnotetext{
18 Singh-Kaur v Ashcroft, 385 F.3d 293 (3rd Cir, 2004).

19 Human Rights First, 'Abandoning the Persecuted: Victims of Terrorism and Oppression Barred From Asylum' (2006); Refugee Council USA, 'The Material Support Problem: Punishing Refugee Victims of Terror: March 8, 2007', available at <http:/ /www.rcusa.org/ uploads/pdfs/ms-backgrd-info3-8-07.pdf>.

2050 USC $\$ \S 1701-06(2000)$.

21 Executive Order 12947 (1995).
} 
the United States to engage in any transactions with the groups, again regardless of the purpose and effect of the support in question. ${ }^{22}$ After the attacks of 11 September 2001, President Bush invoked the same authority to name 27 'specially designated global terrorists'. ${ }^{23} \mathrm{He}$ offered no explanation for why any of them were designated, or any criteria used for the determination. At the same time, he authorised the Secretary of the Treasury to designate still others using extremely broad criteria. Until recently, the Treasury Secretary could designate an individual or entity based solely on a finding that he or it was merely 'otherwise associated with' someone else on the list. ${ }^{24}$

Hundreds of individuals and groups have been placed on this 'terrorist' list since 2001. Remarkably, there is no definition in federal statutes of a 'specially designated terrorist' or a 'specially designated global terrorist'. Thus, the President and the Secretary of Treasury can apply these labels to literally anyone or any group that can conceivably be reached under IEEPA. The only limitation IEEPA places is that there must be some 'foreign interest' in the entity or person designated, but that term has been applied very loosely. Indeed, IEEPA has been used to designate a US citizen, Mohammed Salah, a resident of Chicago. ${ }^{25}$ Under the terms of IEEPA, it is a crime to provide Mr Salah with anything of value, or even to make a donation to him. Literally applied and enforced, the designation would lead to Mr Salah starving to death, since it would be a crime for anyone even to sell or give him a loaf of bread. Yet this penalty was imposed without any jury, without any notice, without any hearing, and without any statutory definition of the label imposed.

Groups or individuals designated under this authority may challenge their designation in federal courts, but as with the State Department list described above, the court will not take any new evidence. The court reviews the designation entirely on the administrative record created by the Treasury Department, in most instances without any input from the designated entity. ${ }^{26}$ Here, too, the government can defend its designation

2250 USC $\S \S 1701-06$.

23 Executive Order 13224 (18 September 2001).

24 In 2006, a federal court declared that provision unconstitutional: Humanitarian Law Project v US Dept of Treasury, 463 F Supp 2d 1049 (CD Cal, 2006). The Treasury Department then amended its regulations to define 'otherwise associated' more narrowly, to mean those entities or individuals that 'own or control; or (b) ... attempt, or ... conspire with one or more persons, to act for or on behalf of or to provide financial, material, or technological support, or financial or other services, to a designated entity': 31 CFR $\S 594.316$ (2007). The district court upheld the term as narrowed: Humanitarian Law Project v US Dept of Treasury, 484 FSupp2d 1099, 1105-07 (CD Cal, 2007).

25 See D Cole, Enemy Aliens: Double Standards and Constitutional Freedoms in the War on Terrorism, revised edn (New York, NY, New Press, 2005) 78.

26 See, eg, Holy Land Foundation v Ashcroft, 333 F.3d 156 (DC Cir, 2003), cert denied, 540 US 1218 (2004); National Council of Resistance of Iran v. Department of State, 251 F.3d 192, 207 (DC Cir, 2001) 
by submitting secret evidence that the court examines outside the presence of the challenger. Here, too, the decks are stacked; no one has yet succeeded in challenging their designation in court. ${ }^{27}$

\section{CONSTITUTIONAL CONCERNS}

The statutes described above prohibit virtually all associational support to selected political organisations, while granting executive branch officials effectively unreviewable discretion to target disfavoured groups. These laws make it a crime to write an opinion piece for a newspaper, provide legal advice, volunteer one's time, or distribute a magazine for any 'designated' group, even if there is no connection whatsoever between the individual's support and any illegal activity of the proscribed group.

Under these statutes, a US citizen who sends a treatise on non-violence to the Kurdistan Workers' Party to encourage it to forgo violence for peace can be sent to prison for 15 years. This is so even if he proves that he intended the treatise to be used only for peaceful ends, and that it was in fact used solely for that purpose. Such a moral innocent can be said to be 'guilty' only by association.

The Supreme Court has declared guilt by association 'alien to the traditions of a free society and the First Amendment itself' ${ }^{28}$ It violates both the Fifth Amendment, which requires that guilt must be personal, and the First Amendment, which guarantees the right of association.

The statutes are analytically indistinguishable from the McCarthy era laws that penalised association with the Communist Party. Congress specifically found that the Communist Party was a foreign-dominated group engaged in terrorism for the purpose of overthrowing the United States. ${ }^{29}$ The Supreme Court did not question that finding, but nonetheless ruled that even with respect to such a group, individuals could not be penalised for their associations absent proof of 'specific intent' to further the group's illegal ends. ${ }^{30}$ The material support statutes require no 'specific intent', and punish people solely for their associational support of specified groups.

\footnotetext{
27 See, eg, Islamic American Relief Agency v Gonzales, 477 F.3d 728 (DC Cir, 2007); Global Relief Foundation, Inc v O'Neil (GRF), 315 F.3d 748 (7th Cir, 2002); Holy Land Foundation v. Ashcroft, 333 F.3d 156 (D.C.Cir. 2003).

28 NAACP v Claiborne Hardware, 458 US 886, 932 (1982).

2950 USC § 781 (West, 1991) (repealed 1993).

30 See, eg, United States v Robel, 389 US 258, 262 (1967) (government could not ban Communist Party members from working in defence facilities absent proof that they had specific intent to further the Party's unlawful ends); Keyishian v Board of Regents, 385 US 589, 606 (1967) ('[m]ere knowing membership without a specific intent to further the unlawful
} 


\section{David Cole}

The courts have nonetheless largely approved of these laws. In the leading case, Humanitarian Law Project $v$ Reno, the US Court of Appeals for the Ninth Circuit concluded that the criminal material support statute is valid because it does not penalise membership as such, but only 'material support'. ${ }^{31}$ Several other courts have adopted that reasoning. ${ }^{32}$ But that distinction makes the prohibition on guilt by association a meaningless formality; instead of criminalising membership of disfavoured groups, legislatures may simply criminalise the payment of dues or volunteering of services to those groups. Since associations cannot exist without the material support of their members, the court's reasoning eviscerates the right of association. ${ }^{33}$

The notion that material support can be penalised even if membership cannot is directly contrary to Supreme Court precedent. In NAACP v Claiborne Hardware, for example, the Supreme Court unanimously held that the leaders and members of the National Association for the Advancement of Colored People (NAACP), a prominent civil rights group, could not be held liable for injuries sustained during an NAACPled boycott that grew violent absent proof that 'the individual[s] held a specific intent to further [the boycott's] illegal aims'. ${ }^{34}$ But if material support is constitutionally distinct from association, the NAACP's thousands of individual donors could have been held liable without any showing of specific intent, even if its leaders could not be.

aims of an organization is not a constitutionally adequate basis' for barring employment in the state university system to Communist Party members); Elfbrandt $v$ Russell, 384 US 11, 19 (1966) ('a law which applies to membership without the "specific intent" to further the illegal aims of the organization infringes unnecessarily on protected freedoms'); Noto $v$ United States, 367 US 290, 299-300 (1961) (First Amendment bars punishment of 'one in sympathy with the legitimate aims of [the Communist Party], but not specifically intending to accomplish them by resort to violence').

31205 F.3d 1130 (9th Cir, 2000), cert denied, 532 US 904 (2001).

32 United States v Hammoud, 381 F.3d 316 (4th Cir, 2004); United States v Assi, 414 F. Supp. 2d 707 (ED Mich, 2006); United States v Paracha, 2006 US Dist LEXIS 1 (SDNY, 2006); Holy Land Foundation for Relief and Development v Ashcroft, 333 F.3d 156 (DC Cir, 2003).

33 As the Supreme Court has said, "The right to join together "for the advancement of beliefs and ideas" ... is diluted if it does not include the right to pool money through contributions, for funds are often essential if "advocacy" is to be truly or optimally "effective"': Buckley v Valeo, 424 US 1, 65-6 (1976) (quoting NAACP v Alabama, 357 US 449, 460 (1958)). Monetary contributions to political organisations are a protected form of association and expression: ibid, at 16-17, 24-5; Roberts $v$ United States Jaycees, 468 US 609 (1984) (First Amendment protects non-profit group's right to solicit funds); Citizens Against Rent Control v Berkeley, 454 US 290, 295-6 (1981) (monetary contributions to a group are a form of 'collective expression' protected by the right of association); Service Employees Int'l Union v Fair Political Practices Comm'n, 955 F.2d 1312, 1316 (9th Cir) ('contributing money is an act of political association that is protected by the First Amendment'), cert denied, 505 US 1230 (1992); In re Asbestos Litig, 46 F.3d 1284, 1290 (3rd Cir, 1994) (contributions to political organisation are constitutionally protected absent specific intent to further the group's illegal ends).

34458 US 886, 920 (1982). 
The asserted distinction between support and membership also cannot be squared with the Fifth Amendment requirement that the government prove personal guilt. In Scales v United States, ${ }^{35}$ discussed in the Introduction, the Supreme Court stated:

In our jurisprudence guilt is personal, and when the imposition of punishment on a status or on conduct can only be justified by reference to the relationship of that status or conduct to other concededly criminal activity, ... that relationship must be sufficiently substantial to satisfy the concept of personal guilt in order to withstand attack under the Due Process Clause of the Fifth Amendment. ${ }^{36}$ (emphasis added)

In other words, the Fifth Amendment forbids holding a moral innocent culpable for the acts of others. The principle is not limited to penalties based on membership alone: it encompasses any punishment of 'status or conduct' that 'can only be justified by reference to the relationship of that status or conduct to other concededly criminal activity'. The prohibition on material support to specified groups is explicitly 'justified by reference to the relationship of that... conduct to other concededly criminal activity', namely the group's 'terrorist activity'.

The asserted distinction between support and membership makes even less sense under the Fifth Amendment principle of personal guilt than under the First Amendment. Surely it seems more reasonable to attribute criminal liability for a gang crime to a member of a violent gang than it would to attribute liability to a social worker who provided the gang with vocational training or counselling services. Yet under the courts' analysis of the 'material support' laws, the gang member could not be held liable absent proof of specific intent to further the gang's illegal ends, but the social worker could be.

The government has argued that broadly criminalising support even of groups' otherwise lawful activities is necessary because money is fungible, and therefore any support, even to legitimate activities, frees up resources that can be used to support a group's illegal activities. That argument proves too much, for it would render nugatory the constitutional ban on guilt by association. The fact that a group engages in illegal activities - even illegal activities that threaten national security - does not permit the government to prohibit association with the group's legal activities. Yet on the government's view, because all support of a group frees up resources that could be used for illegal activities, all support to any group that engages in illegal activities could be criminalised. On this theory, the fact that the Democratic and Republican Parties violate campaign finance laws would authorise a prohibition on all support of

35367 US 203 (1961).

36 Ibid, at $224-5$. 


\section{David Cole}

those parties. The United States made just such a broad 'freeing-up' argument to the Supreme Court in Scales $v$ United States as a reason for rejecting the specific intent test, without success. ${ }^{37}$

In addition, neither these statutes nor the United States' enforcement of them is consistent with the freeing-up theory. As noted above, the criminal material support statute itself permits unlimited donations of 'medicine and religious articles' to terrorist groups. ${ }^{38}$ Yet donations of medicine and religious articles are just as capable of freeing up resources as the prohibited donations. And the statute contemplates approval of certain forms of training, expert advice or assistance, and personnel, where the support may not be used to carry out terrorist activity. But under the government's theory, it should not matter if the support itself may be used to pursue terrorism, because even if it cannot, it theoretically frees up other resources that can be so employed.

The courts have recognised that the breadth of the material support statutes is troubling, and have invalidated the laws at their furthest reaches. Thus, several courts have ruled that the definition of 'material support' is too broad, and have struck down as unconstitutionally vague the prohibitions on providing 'training', 'expert advice or assistance' and 'services' to terrorist groups. ${ }^{39}$ In addition, a federal court ruled unconstitutional the President's authorisation to the Secretary of the Treasury to designate 'specially designated global terrorists' on the basis of mere association and, as noted above, in the wake of that decision, the government narrowed the 'association' ground considerably. ${ }^{40}$ These decisions have been important in reining in the worst excesses of the material support regime. But they leave in place its fundamental infirmity - the imposition of guilt by association.

Similarly, the courts have generally upheld the procedures employed for designated entities to challenge their designation - while rejecting all challenges that have come before them. The courts have to date permitted the government to defend its designations using secret evidence not

\footnotetext{
37 Brief for the United States on Reargument at 8, Scales v United States, 367 US 203 (arguing that showing 'specific intent' is unnecessary 'on the principle that knowingly joining an organization with illegal objectives contributes to the attainment of those objectives because of the support given by membership itself').

3818 USC $\S 2339$ A $(b)$

39 See Humanitarian Law Project v Reno, 205 F.3d 1130 (9th Cir, 2000) (declaring 'training' and 'personnel' unconstitutionally vague); Humanitarian Law Project $v$ Gonzales, 380 F.Supp.2d 1134 (CD Cal, 2005) (declaring 'training'. 'expert advice or assistance', and 'services' unconstitutionally vague); United States $v$ Sattar, 272 F.Supp.2d 348 (SDNY, 2003) (declaring 'personnel' and 'communications' unconstitutionally vague).

40 See n 24 above.
} 
disclosed to the challenger, and have declined to accept evidence proffered by the designated entities, limiting their decisions to the administrative record. ${ }^{41}$ The courts have required that where a designated entity has a presence within the United States, due process requires that it be afforded an opportunity to make a presentation in writing, to be included as part of the administrative record. But that is the extent of the entity's opportunity to defend itself. No hearing is required, and accordingly there is no opportunity to present witnesses or to confront the government's witnesses. ${ }^{42}$

To adhere to the constitutional prohibition on guilt by association and bar criminalisation of material support without a showing of intent would not leave the nation defenceless against terrorist plots. There are many more precisely calibrated ways to stem the flow of funds for terrorist activity. Congress can make and has made it a crime to provide material support to a wide range of terrorist crimes. ${ }^{43}$ Conspiracy and 'aiding and abetting' statutes penalise not only those who actually commit acts of violence, but also those who engage in overt acts in furtherance of such conduct, even if the ultimate wrongdoing never comes to fruition. ${ }^{44}$ Money laundering statutes expressly prohibit the transmission of money or funds with the intent of promoting terrorist activity. ${ }^{45}$ And the Racketeering Influenced and Corrupt Organizations Act (RICO), permits the government to target ostensibly legitimate activities when they are a front for illegal conduct. ${ }^{46}$ Thus, the constitutional prohibition on guilt by association permits the government to criminalise the financing of terrorism. It simply requires it to target terrorism rather than political association.

The international approach to terrorist financing illustrates a greater sensitivity to concerns about guilt by association than is reflected by the US regime. The United States has actively encouraged other nations to

41 See, eg, Holy Land Foundation v Aschroft, 333 F.3d 156.

42 National Council of Resistance to Iran v Department of State, 251 F.3d 192 (DC Cir, 2001).

4318 USC §2339A(a) (criminalising aid to a long list of specific terrorist acts).

44 Sheikh Omar Abdel Rahman, for example, was convicted of seditious conspiracy for his part in encouraging a plan to bomb various tunnels and bridges in New York City, even though he did not undertake any violent act himself: United States v Rahman, 189 F.3d 88 (2nd Cir, 1999), cert denied, 528 US 1094 (2000).

45 The Money Laundering Control Act makes it a crime, among other things, to transmit funds 'with the intent to promote the carrying on of specified unlawful activity', including terrorism: 18 USC §1956(a)(2)(A). The USA PATRIOT Act added extensive new money laundering provisions designed to facilitate the investigation, prevention, and prosecution of money laundering related to terrorism: USA PATRIOT Act, $\$ \S 301-76$.

4618 USC §§ 1961-8. RICO prohibits the acquisition or maintenance of any enterprise through a pattern of racketeering, or with income derived from a pattern of racketeering: 18 USC $\S 1962$. A wide range of terrorist activity and fundraising for terrorist activity is included within the definition of racketeering activity: see 18 USC § 1961(1) and 18 USC § $2332 b(g)(5)$. 
crack down on 'terrorist financing', and shortly after 11 September 2001 convinced the UN Security Council to issue Resolution 1373. That resolution, however, calls on all UN member states to enact laws criminalising the willful provision or collection of funds with the knowledge or intention that they will be used to carry out terrorist acts, and thus is in keeping with a requirement of individualised intent. ${ }^{47}$ States are required to freeze the assets of persons who facilitate terrorist acts. ${ }^{48}$

Many nations have responded, but generally by penalising only those who provide material support with the intent of furthering terrorist acts, not those who merely support a group without any intent to further its criminal ends. The European Union, for example, maintains a list of terrorist groups and supporters. ${ }^{49}$ Funds of those listed are frozen, and the European Community is required to ensure that assets will not be made available to the parties on the list. ${ }^{50}$ A European Council Framework Decision of June 2002 on combating terrorism requires member states to make it a crime to 'participate in the activities of a terrorist group, including by supplying information or material resources, or by funding its activities in any way, with knowledge of the fact that such participation will contribute to the criminal activities of the terrorist group' (emphasis added). ${ }^{51}$ That formulation respects the principle of individual culpability that the United States has abandoned.

These laws illustrate that it is possible to target terror financing while being attentive to the distinction between intentional support of terrorist acts, and aid to terrorist groups that is intended to further only lawful ends. The European courts have also demanded greater procedural protections for those who challenge their inclusion on the list, requiring, for example, a statement of reasons and the right to a fair hearing. ${ }^{52}$

In short, the United States' approach to material support for terrorist organisations contravenes basic constitutional principles of fairness, due process and the right of association. There are more narrowly tailored alternatives available, as illustrated by the other US laws discussed above, and by the responses of other nations to the same problem. Here, as elsewhere in the 'war on terror', the United States has gone out on a limb.

47 UN Security Council Resolution 1373, Art 1(b).

48 Ibid, Art 1(c).

49 The latest complete version of this list is at Council Common Position 2006/380/CFSP of 29 May 2006, OJ L 144 p 25. (DOC 9).

50 2001/931/CFSP, Council Common Position of 27 December 2001 on the application of specific measures to combat terrorism, OJ 2001 L344/93, at Arts 2 and 3. (DOC 10).

51 EC Council Framework Decision of 13 June 2002 on Combating Terrorism, Art 2.2(b).

52 Organisation des Modjahedines du people d'Iran v Council of the European Unio, Court of First Instance of the European Communities (Second Chamber) (12 December 2006). 


\section{THE BROADER CONTEXT - THE PREVENTIVE PARADIGM}

The material support regime is just one part of a much broader initiative launched by the Bush administration in the wake of 11 September 2001. The administration insisted that 'everything changed' after that date, and that it must operate within a new paradigm of prevention. When suicide bombers attack, prosecution after the fact is a patently insufficient response - it is far better to stop them before they act. Citing the need to prevent terrorist attacks, the administration has invoked the 'preventive paradigm' at home and abroad as a justification for abandoning traditional limits on the use of coercive state power, and thereby freeing the state to use force not merely reactively, to defend against attacks or to punish wrongdoers, but proactively, to prevent terrorist attacks before they are launched. ${ }^{53}$

The preventive rationale is what the United States used to justify its decision to launch a war against Iraq. The Pentagon's 2002 National Security Strategy advanced a new and controversial 'preventive' justification for going to war, arguing that in light of the threats now posed by weapons of mass destruction, war is justified not only when the nation is under attack or the threat of imminent attack - the only justifications recognised by international law - but also when it faces a more speculative but potentially catastrophic future threat. ${ }^{54}$ No one argued that an attack by Iraq on the United States was imminent. Instead, the administration contended that the potential for attack with weapons of mass destruction at some undetermined time in the future and by some undetermined terrorist group that might obtain the weapons from Saddam Hussein was sufficient to justify war as a preventative measure.

The administration has similarly defended the use of cruel, inhuman, and degrading treatment to interrogate al Qaeda suspects on the ground that the information so obtained may help prevent future attacks. No one defends torture or coercive interrogation as a way of solving past crimes or punishing perpetrators - the only justification offered is the forwardlooking one of preventing future harms. And the administration has also cited a 'new paradigm' to argue that the Geneva Conventions and other rules of war do not apply to the conflict with al Qaeda. It claimed that the Geneva Conventions apply only to wars between nations and internal civil wars, and that therefore traditionally recognised rules of war, including the obligation to treat detainees humanely, are inapplicable at

\footnotetext{
53 For a more complete discussion and critique of the 'paradigm of prevention' discussed here, see D Cole and J Lobel, Less Safe, Less Free: Why America is Losing the War on Terror (New York, NY, The New Press, 2007).

54 The White House, National Security Strategy of the United States of America, 17 September 2002, available at <http://www.whitehouse.gov/nsc/nss.all.html>.
} 
Guantanamo and at secret CIA 'black sites' where al Qaeda detainees are held. ${ }^{55}$ Here, too, the motive for denying Geneva Conventions protection was precisely to allow interrogators to use coercive means to extract intelligence from suspects.

At home, Attorney General John Ashcroft repeatedly trumpeted a parallel new 'paradigm of prevention' in law enforcement and intelligence gathering. ${ }^{56}$ Asserting that it would help prevent the next attack, the administration subjected 82,000 Arab and Muslim immigrant men to fingerprinting and registration, subjected 8,000 Arab and Muslim men to FBI interviews, and preventively detained over 5,000 foreign nationals, also nearly all Arabs and Muslims. ${ }^{57}$ As part of its preventive paradigm, the government adopted an aggressive strategy of arrest and prosecution on 'pretextual' minor charges - such as immigration violations, credit card fraud or false statements - or on no charges at all, as 'material witnesses', when it suspected them of terrorist ties but lacked the evidence to try them for terrorism. On a similar preventive rationale, the administration pushed for expansive new powers in the USA Patriot Act, and since then the FBI has used that Act to issue annually tens of thousands of 'national security letters' - administrative subpoenas that demand the secret production of information on customers from telephone and internet companies and financial institutions without any court review. ${ }^{58}$ And most recently, the preventive rationale has been advanced to justify the National Security Agency's (NSA's) warrantless wiretapping of countless persons in the United States, without congressional or judicial approval, pursuant to an executive order adopted in secret and in contravention of a criminal prohibition on such surveillance. 59

The same preventive rationale underlies the material support laws. The justification for criminalising human rights advocacy training or humanitarian aid is not that such support is itself somehow morally wrong, or harmful. The argument is that if we cut off all support to

55 The White House, Fact Sheet on Status of Detainees, 7 February 2002, available at <http://www.whitehouse.gov/news/releases/2002/02/20020207-13.html>.

56 See $\mathrm{n} 8$ above.

57 See Cole, n 25 above, at 25-35.

58 US Dept of Justice, Inspector General, A Review of the Federal Bureau of Investigation's Use of National Security Letters (March 2007), available at <http:/ /www.usdoj.gov/ oig/special/s0703b/final.pdf >; D Eggen, 'FBI Sought Data on Thousands in '05' The Washington Post, 2 May 2006, A4.

59 In a radio address following disclosure of the NSA warrantless wiretapping program, President Bush argued that 'the activities conducted under this authorization have helped detect and prevent possible terrorist attacks in the United States and abroad': GW Bush, 'The President's Radio Address' 17 December 2005, available at <http:/ / www.whitehouse. gov/news/releases/2005/12/20051217.html>; see also R Stevenson and A Liptak, 'Cheney Defends Eavesdropping Without Warrants', New York Times, 21 December 2005, A36. 
entities and individuals we label as 'terrorists', we will make it more difficult for these entities and individuals to carry out terrorist activity in the future. Thus, while material support laws as a formal matter punish past acts, not future predictions, the justification for punishing the past acts is the speculation that they might facilitate bad acts in the future.

Whether in the context of material support, interrogation, detention or war-making, the preventive paradigm puts tremendous pressure on the values we associate with the rule of law. Designed to place enforceable constraints on state power, the rule of law generally reserves detention, punishment and military force for those who have been shown, on the basis of sound evidence and fair procedures, to have committed some wrongful act in the past that warrants the government's response. The administration's 'preventive paradigm', by contrast, justifies coercive action - from detention to torture to bombing - on the basis of speculation about future contingencies, without either the evidence or the fair processes that have generally been considered necessary before the state imposes coercive measures on human beings.

When the state begins to direct highly coercive measures at individuals and other states based on necessarily speculative predictions about future behaviour, it inevitably leads to substantial compromises on the values associated with the rule of law - such as equality, transparency, individual culpability, fair procedures and checks and balances. We have seen just those compromises in the context of the material support laws. Groups are selected for designation in a necessarily subjective and secretive process, and denied a meaningful opportunity to challenge their designations. Individuals are then held responsible not for their own acts, but for their associational support of others, without regard to whether the individual being punished has ever done anything to facilitate violence. And the material support laws frustrate checks and balances by granting the executive branch wide leeway in designation decisions, and by providing for only a charade of judicial review.

\section{CONCLUSION}

Many of the United States' initiatives in the 'paradigm of prevention' have come back to haunt it. Guantanamo and Abu Ghraib have done incalculable damage to the United States' image abroad. The round-up and preventive detention of thousands of Arab and Muslim immigrants within the United States after 11 September 2001, none of whom had any connection to terrorism, has alienated Arab and Muslim communities both at home and abroad, and the war in Iraq has been an unmitigated disaster. 
The reason these measures have backfired is because they are so inimical to the core values of the rule of law. So, too, the punishment of material support, a twenty-first century version of guilt by association, is contrary to fundamental principles, not only of US constitutional law, but of international human rights law. In the long run, like other preventive paradigm initiatives, it is likely to alienate potential allies, fuel the propaganda of enemies, and inflict unnecessary harm on both the moral innocents targeted, and on the reputation of the United States worldwide. A lot may have changed after 11 September 2001, but not the need to respond to wrongdoers within the framework of the rule of law. 